\title{
Mindset Kinetics-Under Toxicological Aspect
}

\author{
Luisetto $\mathbf{M}^{1 *}$, Behzad Nili Ahmadabadi ${ }^{2}$ and Ghulam Rasool Mashori ${ }^{3}$ \\ ${ }^{1}$ Department of applied pharmacologist, Italy \\ ${ }^{2}$ Pharm D/PhD innovative Pharmaceutical product development specialist, USA \\ ${ }^{3}$ Department of Medical \& Health Sciences for Woman, Peoples University of Medical and Health Sciences for Women, Pakistan
}

Submission: January 04, 2018; Published: January 08, 2018

*Corresponding author: Luisetto M, Department of applied pharmacologist, Italy, Email: maurolu65@gmail.com

\section{Introduction}

We can see that the AMOUNT of stress ant stimulus and related KINETICS are relevant factors involved in some human conditions. Not only the single stress but the global amount in a limited time are involved in this situation and a chronic condition make more severe this situation. The same not all individuals react the same level and not all have resilience ability as needed. But the single resilience ability depends only from psycologic status? Or other factors are involved?

Can we compare the mindset kinetics to other metabolic kinetics? Are really so different this aspects?

Can we think to a sort of saturate condition in some situation?

Can we think to a maximal velocity in management of simultaneous or high stress ant stimulus?

Why some individuals react in very different way?

Can we apply E. Goldratt TOC Theory of constraints in this kind of situations to explain some Psychological pathways?

Brain and mind follow the same principle? (Limitanting factors?)

"We start our paper observing that in past centuries physicians in some cardiologic disease were used to prescribe to the patient to take a long rest in order to recuperate their health status. In past centuries it wasn't available high efficient drugs strategies and so to take a long rest without physical and psychological stress contributes to this process. Also in oriental medicine we can see body balances strategies, and also in some psycoaanalitc techniques we can see that time is relevant to reequilibrate some conditions (in example acute stress). We can think that the main factors involved are TIME and LONG REST in order to balance the physiologic functions. In some case it was observed complete resolve in some situations. In example we can think that a metabolic unbalances can create this situation and the time make possible to restore [1]." a) "As observed in other scientific or medical discipline controlling some non physiological cellular activity. Results in reducing of abnormal organ activation. The same way we can think that some neuronal transmission pathway can be better pharmacologically modulated In order to have in example relevant reduction in amygdala disfunctions [2]."

b) "Emotional processing and learning, and several social and affective decisions making functions are impaired in psychopathy, which correlates with specific changes in neural functions"

c) "About $70 \%$ of works ability and success depends on emotional intelligence versus $30 \%$ technical abilities (Remember Pareto paradigm 20/80 similar). The emotional intelligence theory shows that the emotional brain can be more rapid in responding to some stress stimulus then the rational thinking.

For example studies showed that Amygdala physio-pathology is involved in E. I. management and can give in thissituation rapid response without waiting for the cortical brain control. (Neo-cortex/reptilian brain) [1]. When in the same time many strong emotions stimulation arrives too fast to amygdala the neo cortex is not involved [2]. An easy reactive amygdala can results in working difficulties in relationship in equip. Low level of social intelligence gives isolation and depression and low working performances. Conflict are natural in all context and so in working setting. The self-motivation is strongly involved in professional development. Successful status is related with high emotional, social and political attitudes [3]. But even if the technical competences are subjects of usual educational and university policy we see a real gap for the emotional social and relational development in student curriculum. So in this work, we try to give some elements for improving behavior skills to be active and efficient part of a professional team or to prevent and resolve conflict [4]. In our opinion some theory are to be 
post under right light: and for example: De Bono Seven hats and Lateral thinking (problem solving approach), E. Goldratt TOC Theory of constraints, about psychological limits (a management theory), translational analysis, emotional and social intelligence, Pareto paradigm, GANTT diagram, Eisenhower matrix, Deming cycle (total quality management), MASLOV hierarchy of need, but they only the first of many other" [5].

\section{Discussion and Conclusion}

Under the light of the citated literature and other biomedical article available we can observe that in order to evaluate stressing situation are fundamental : kind of stress (in example HIGH or not); amount of global stressing condition, simultaneous; duration of stimulus (cronic conditions?) individual status (resilience?, stress management ability, depression) psycologic but also genetic; kinetics. We have seen that in order to improve resilience abilities are usefull many techniques in order to balance the mindset activity.

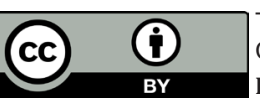

This work is licensed under Creative Commons Attribution 4.0 License

DOI: $10.19080 /$ PBSIJ.2018.08.555731
If unbalanced results in an inadeguate kinetics with an inappropriate global response. We think that also this condition must be evaluated under a kinetic- toxicological aspect to clear the basic Phisio-patogeneticmovens. A deep knowledge in some process can be usefull also in pharmacological new strategies finding today not travelled as request.

\section{References}

1. Luisetto M (2017) Intra- Local Toxicology Aspect Time Related in Some Pathologic Conditions. Open Acc J of Toxicol 2(3): 002555586.

2. Luisetto M (2017) Brain and Transmission Signal Modulation. Theranostics Brain Disord 1(1): TBD.MS.ID.555553.

3. Del Casale (2015) Functional Neuroimaging inPsychopathy. Neuropsychobiology 72(2): 97-117.

4. Mauro L, Ahmad Khan F, Luca C, Nili B (2016) Amygdala pharmacology and crime behavior, dysfunctions to be considered as a disease. International Archives of Bio Medical and Clinical Research 2(1): 1-4.

5. Mauro L (2017) Attitudes and Skills in Business Working Settings: A HR Management Tool Bus Eco J 8: 291.

\section{Your next submission with Juniper Publishers will reach you the below assets}

- Quality Editorial service

- Swift Peer Review

- Reprints availability

- E-prints Service

- Manuscript Podcast for convenient understanding

- Global attainment for your research

- Manuscript accessibility in different formats ( Pdf, E-pub, Full Text, Audio)

- Unceasing customer service

Track the below URL for one-step submission https://juniperpublishers.com/online-submission.php 